\title{
Om Ernst A. Kiørboe
}

\section{Komponist til den vestslesvigske hjemstavnssang "For en fremmed barsk og fattigt«}

\author{
af Kaj SøRensen
}

I 1922 skrev daværende lektor ved Tønder Statsskole Andreas Egeberg Jensen sin lovprisning til Vestslesvig og egnen omkring Tønder For en fremmed barsk og fattigt. Samme år komponerede hans kollega Emst A. Kiørboe melodien, og sangen blev første gang sunget ved Tønder Statsskoles translokation i 1922. Den blev trykt i skolens årsskrift 1923. Siden er sangen næsten blevet en sønderjysk »nationalsang «. Her fortæller organist Kaj Sørensen, Tåstrup, efter omfattende studier og kontakt med familien om komponisten og hans miljø.

I årene efter Genforeningen var der i Tønder kun få fritidstilbud til børn og unge. Derfor så nogle af statsskolens unge lærere, deriblandt Egeberg Jensen, ${ }^{1}$ det som deres opgave at tage sig af drengene i deres fritid og arrangerede bl.a. cykelture i omegnen. På disse ture blev der sunget meget, og mange af sangene, bl.a. Vi drenge fra Tønder, skrev Egeberg Jensen selv.

En dag besluttede Egeberg Jensen, at han ville lave en skolesang, der kunne synges af alle - også af pigerne - og så skrev han For en fremmed barsk og fattigt. Ernst Kiørboe satte melodi til teksten, og sangen blev i løbet af få år den hyppigst sungne sang på Tønderegnen. ${ }^{2}$ Den kom med i den sønderjyske sangbog, Den Blå Sangbog, men blev også kendt ud over landsdelen. Sangen blev første gang optaget $i$ Højskolesangbogen i 13. udgave, der udkom i 1939, og har været med i samtlige udgaver siden.

Det er blevet sagt, at For en fremmed barsk og fattigt er blevet til, fordi forfatter og komponist gerne så lidt andet sat i stedet for den da meget sungne Det haver så nyligen regnet. Det benægter Ernst Kiørboe imidlertid og anfører, at de fra starten overhovedet ikke nærede nogen som helst forestillinger om, at sangen ville nå ud over statsskolens grund. ${ }^{3}$

Kiørboes melodi er skrevet i Es-dur, og det er ganske givet ikke nogen tilfældighed, at han valgte netop den toneart. Der er over Es- 


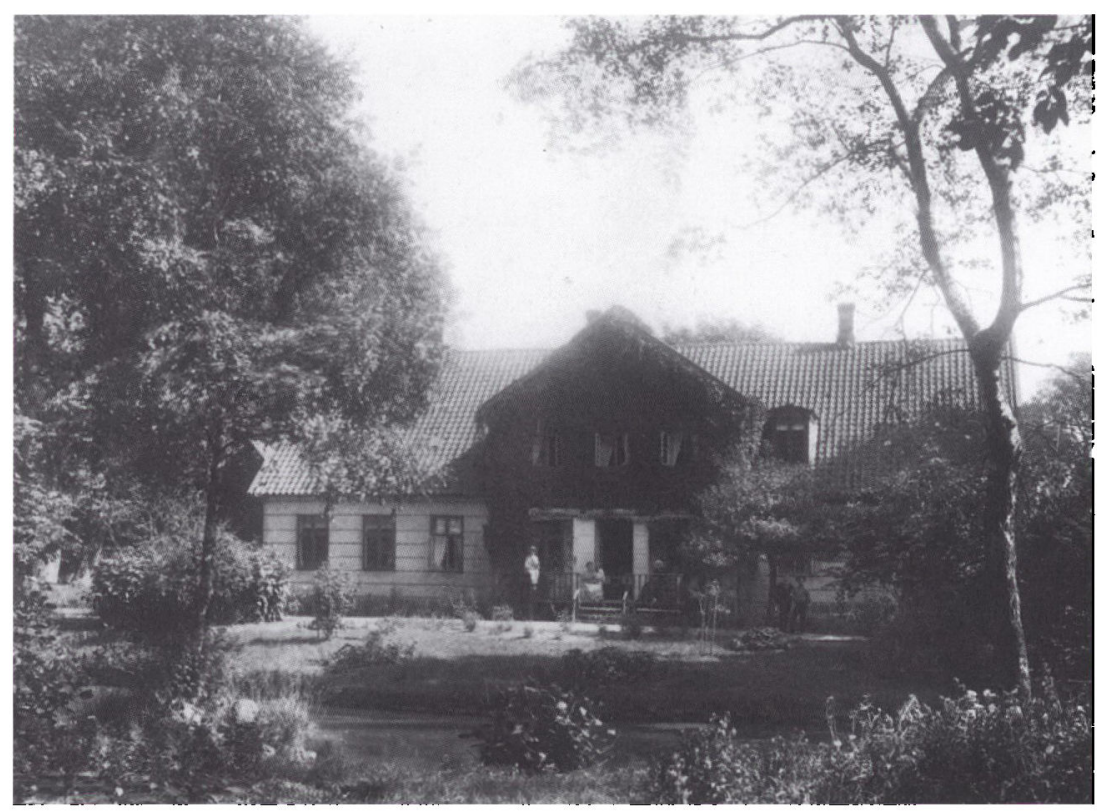

Præstegården i Ulstrup, Ernst Kiørboes barndomshjem, fotograferet $i$ sommeren 1899, få dage for faderen tiltrådte embedet som sogneprast ved Sct. Nicolai kirke $i$ Kolding. Præstegården eksisterer ikke mere, den blev nedrevet $i$ 1950'erne. Foto $i$ Kalundborg Lokalhistoriske Arkiv.

durtonearten noget heroisk, noget storladent, og netop derved kom melodien til at passe fortrinligt til Egeberg Jensens tekst med dens lovprisning af vesteregnens høje, lyse himmel og de langstrakte vidder.

Det er intet mindre end en fremragende melodi Kiørboe her har lavet. Men hvem var han egentlig? Hvad beskæftigede han sig i øvrigt med? Og har han skrevet andre ting end denne melodi?

Nedenfor vil jeg forsøge at tegne et billede af manden bag melodien.

\section{Barndom og uddannelse}

Ernst August Kiørboe blev født den 11. februar 1883 i Refsnæs (nu Røsnæs) Præstegård i Ulstrup by som søn af sognepræst til Refsnæs Carl William Kiørboe og hustru Susanne Sophie Elizabeth Henriette K., født Laub. ${ }^{4}$ Han blev døbt i Refsnæs Kirke den 26. marts 1883. 
Ernst Kiørboe fik i vuggegave rige musikalske evner, som han dyrkede og udviklede livet igennem. Fra faderen arvede han en smuk sangstemme, men det var nok især fra moderens slægt, hans musikalitet stammede. Moderen var kusine til kirkesangsreformatoren, organist Thomas Laub, ${ }^{5}$ der i øvrigt sad ved orglet, da Ernst Kiørboes forældre blev gift i Garnisons Kirke i Kobenhavn den 29. august 1877. Desuden var Ernst Kiørboe - ligeledes på mødrene side - tipoldebarn af organist, musikpædagog, professor, syngemester ved Det kgl. Teater H. O. C. Zinck, ${ }^{6}$ komponist bl.a. til salmemelodierne $\mathrm{Nu}$ kom der bud fra englekor og $\mathrm{Nu}$ rinder solen op af østerlide.

De økonomiske forhold i hjemmet $\mathrm{i}$ Refsnæs Præstegård var ikke særlig gode, men Ernst Kiørboe og hans søskende fik alligevel menneskeligt og udviklingsmæssigt set en uforlignelig start på livet. Forældrene fik i alt otte børn, fem drenge og tre piger, hvoraf to af pigerne døde som helt små.

Ernst Kiørboes fire år ældre bror, Frederik, ${ }^{7}$ fortæller følgende om barndomshjemmet i Refsnæs Præstegård: »Det hjem, som far og mor skabte sig og os børn på dette dejlige sted, var et lykkeligt hjem. Ikke på grund af rige materielle kår; thi fars økonomiske kår var dengang små, hvad vi børn dog aldrig mærkede noget til. Men på grund af den åndelige rigdom, som de hver især sad inde med og forstod at gøre hinanden og deres omgivelser delagtig i, blev deres samliv med hinanden og med deres børn til stor velsignelse. Den afsides beliggenhed, som vort hjem havde, førte uvilkårligt til, at vi levede et udpræget hjemmeliv, og vore forældre gav sig derfor ualmindelig meget af med os ... Så godt som alle vinteraftnerne, når far havde tid, læste han højt hjemme, mens vi børn broderede korsstingsbroderi eller strikkede, alt under mors ledelse. Far læste mange forskellige genrer: Holbergs komedier, Oehlenschlægers tragedier, Hostrups komedier, Heibergs vaudeviller, Ingemanns romaner, Paludan-Müller, Dickens o.s.v.«. 8

Den første skoleundervisning fik børnene af deres forældre. Senere overtog en huslærerinde en del af undervisningen, mens faderen fortsatte med at undervise børnene i latin, matematik og bibelhistorie. ${ }^{9}$

I august 1895 blev Ernst Kiørboe optaget på Sorø Akademi i II klasse. Familien var godt bekendt med Sorø Akademi, idet broderen Frederik et par måneder tidligere var udgået fra akademiet med en præliminær-eksamen, og broderen Otto ${ }^{10}$ rykkede i august 1895 op i skolens IV klasse. 
Standpunktsmæssigt klarede Ernst Kiørboe sig fint på Sorø Akademi. ${ }^{11}$ I 1897 anbefaler rektor således, at faderens ansøgning om en legatportion af Det Müllerske Legat ${ }^{12}$ for skoleåret 1897/98 imødekommes, idet Ernst Kiørboe er »i meget god fremgang«. Resultatet blev, at ministeriet tildelte ham en legatportion på hele $300 \mathrm{kr}$. for det omtalte skoleår, det højeste beløb, der blev uddelt det år. ${ }^{13}$ Beløbet synes ikke af meget i dag, men den tildelte legatportion, som var lig med en hel månedsløn for hans far, har givetvis lunet gevaldigt.

Det ser ud til, at Ernst Kiørboe befandt sig udmærket som elev på Sorø Akademi, og at han havde gavn og glæde af årene dér. Tilsyneladende har der i hele skoleforløbet kun været ganske få problemer. ${ }^{14}$ I 1899 afsluttede han næstsidste klasse med 1. karakter, ${ }^{15}$ og i foråret 1900 bestod han studentereksamen, ligeledes med 1 . karakter. ${ }^{16}$ Dermed var årene på Sorø Akademi slut.

Blandt andet på grund af økonomiske problemer var faderen, William Kiørboe, i 1895, efter 13 år i Refsnæs, begyndt at søge et mere indbringende embede. I marts 1899 søgte han sognepræsteembedet ved Sct. Nikolai Kirke i Kolding, byens dengang eneste kirke, med et sogn på ca. 13.000 indbyggere mod Refsnæs sogns ca. $900 !{ }^{17}$ William Kiørboe blev indstillet til embedet som nr. 1 og udnævnt i maj 1899. Han blev indsat $i$ slutningen af juni samme år. Embedets nettoindtægt var på ca. kr. 5.200 årligt. $^{18}$

I efteråret 1900 flyttede Ernst Kiørboe til København. Han lejede sig ind $\mathrm{i}$ en kvistlejlighed i Kronprinsensgade 11 til en årlig husleje af $400 \mathrm{kr}^{19}$ Der var dog heldigvis fire om udgiften, idet Ernst Kiørboe delte lejligheden med sine to brødre, Frederik og Otto, samt med arkitektstuderende Carl Fr. Schiøtz, der seks år senere blev far til sangeren Aksel Schiøtz. ${ }^{20}$

Flytningen til Kobenhavn skyldtes, at Ernst Kiørboe den 29. september 1900 skulle begynde som studerende ved Københavns Universitet, hvor han valgte at læse fransk som hovedfag og engelsk og latin som bifag. I juni 1901 bestod han Den filosofiske Eksamen. ${ }^{21}$

I perioden efteråret 1903-sommeren 1904 afbrød Ernst Kiørboe sine studier og tog et job som huslærer hos driftsbestyrer Aage Bentzon på »Kløverbakken « ved Odder. ${ }^{22}$

Fra efterårssemestret 1904 genoptog Ernst Kiørboe sine studier ved universitetet og boede 1905-07 på Regensen.

I juni 1906 afsluttede Ernst Kiørboe bifagseksamen i latin og engelsk. Han skrev i 1907 specialeopgave i hovedfaget fransk over 
Kursuslæreren Ernst Kiørboe. Foto maj 1910 i Lokalhistorisk Arkiv for Tonder kommune.

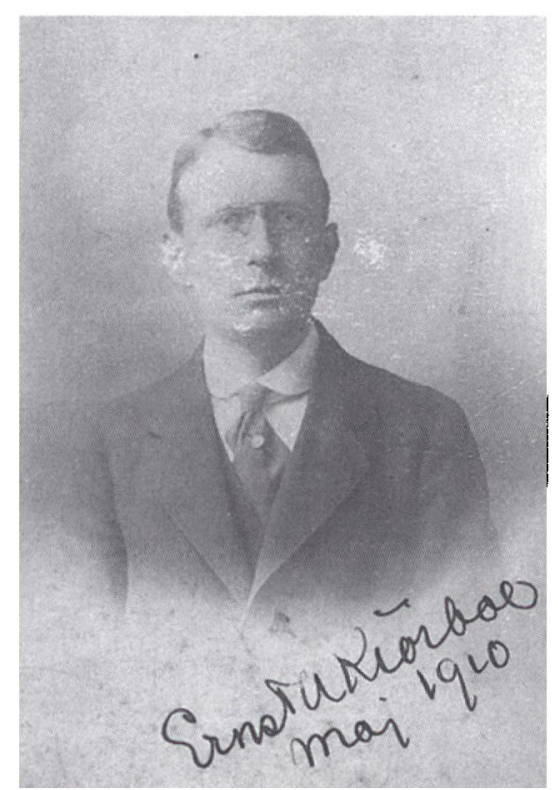

emnet "Novellen i Frankrig i det 19. århundrede" og bestod $\mathrm{i}$ januar 1908 hovedfagseksamen i fransk. ${ }^{23}$ Ernst Kiørboe havde dermed afsluttet skoleembedseksamen. Han opnåede 1. karakter og var nu cand.mag.

Både $\mathrm{i}$ studietiden og $\mathrm{i}$ årene $\mathrm{i}$ Kobenhavn efter embedseksamen dyrkede Kiørboe musikken. Allerede i september 1900 blev han optaget i Cæciliaforeningens Kor som 1. bas og sang i koret under Frederik Rungs ledelse, indtil han rejste til Odder i 1903. ${ }^{24}$ Også klaverspillet blev der i Kobenhavn tid til at videreudvikle. Det skete hos en af datidens kendteste klaverpædagoger, Henrik Knudsen, ${ }^{25}$ samtidig med, at han fik undervisning i musikteori af Carl Nielsen.

Ud over en bestået skoleembedseksamen og et fire måneders studieophold i Paris skete der i 1908 yderligere det betydningsfulde for Kiørboe, at hans morbror, arkitekt Ditlev Laub, ${ }^{26}$ der var bosat i USA, kom på besøg i Danmark med en del af sin familie, nemlig hustruen samt to døtre og en søn. Den ene af døtrene, Gwendolynne Laub, ${ }^{27}$ og Ernst Kiørboe fattede interesse for hinanden. De forlovede sig i 1909 og giftede sig i 1916. 


\section{Første embeder}

Efter Parisopholdet i 1908 boede Kiørboe en tid hos sin far i præstegården $\mathrm{i}$ Kolding, men flyttede derefter atter til Kobenhavn, hvor han pr. 1. august 1908 blev ansat ved De forenede Kursus ${ }^{28}$ som fransklærer med en lon på 1 kr. pr. undervisningstime. I skoleåret 1910/11 fik Kiørboe desuden timer i engelsk.

Via sin fætter og senere svoger, Desmond Laub, fik Ernst Kiørboe i perioden 1911-13 en stilling som fransklærer ved Horace Mann School i New York. Skolen besøgtes fortrinsvis af børn fra rige familier, deriblandt mange jøder. I New York fik Ernst Kiørboe også lejlighed til at besøge sine senere svigerforældre samt sin forlovede, Gwendolynne. Moderen var katolik og ikke alt for begejstret for datterens forlovelse med en protestant, der oven i købet var Gwendolynnes fætter. ${ }^{29}$

Efter hjemkomsten til Danmark tilbragte Ernst Kiørboe atter nogle måneder hos faderen i Kolding og blev derefter i 1914 genansat ved De forenede Kursus i København, denne gang til en timeløn på 1,25 kr. Desuden blev han fra 1914 ansat som lærer ved den nyoprettede Københavns Translatørskole. ${ }^{30}$

I sommeren 1918 flyttede Ernst og Gwendolynne Kiørboe fra Nørregade 27 i København til præstegården i Hyrdestræde i Kolding. Anledningen var, at Kiørboe pr. 1. august var blevet udnævnt til adjunkt i fransk og engelsk ved Kolding højere Almenskole, ${ }^{31}$ og da der var god plads i præstegården, foreslog William Kiørboe, at sønnen og svigerdatteren kunne bebo et par af værelserne dér, mod at Gwendolynne til gengæld sørgede for alt vedrørende husholdningen. ${ }^{32}$ De boede $\mathrm{i}$ præstegården $\mathrm{i}$ to år, indtil de $\mathrm{i}$ sommeren 1920 flyttede til Tønder, hvor Ernst Kiørboe pr. 1. august var blevet udnævnt til lektor ved den nyoprettede statsskole. På Kolding højere Almenskole underviste Kiørboe begge år 33 timer ugentligt i fransk $\mathrm{i}$ gymnasiet og i engelsk i mellemskolen. Begyndelseslønnen for en adjunkt var i $19183.480 \mathrm{kr}$. årligt, hvortil kom enkelte mindre tillæg, fx hvis der blev læst over 12 timer ugentligt i gymnasiets eksamensfag. ${ }^{33}$ På Ernst Kiørboes ansøgning i foråret 1920 om et lektorembede ved statsskolen i Tønder, skrev Kolding højere Almenskoles rektor en anbefaling, der sluttede således: "Hans bortgang fra vor skole vil være et tab for vor undervisning, og han vil være en vinding for enhver skole, der knytter ham til sig «. ${ }^{34}$ 


\section{Ansøgning om Tønder}

Det vides ikke bestemt, hvorfor Ernst Kiørboe i 1920 søgte embedet ved Tønder Statsskole.

Måske ville både han og Gwendolynne gerne væk fra præstegården i Kolding for igen at få deres eget hjem. Det kan være en mulig årsag. Forholdet til faderen synes dog at have været vældig godt. Da William Kiørboe i februar 1926 var blevet pensioneret, flyttede han straks - på Ernst og Gwendolynnes opfordring - til deres hjem i Havehuset i Carstensgade 11 i Tønder. Det blev i 1926/27 udvidet med en første sal, så der blev rigelig med plads til dem alle tre. Her boede William Kiørboe til sin død i december 1930, og han slutter sin selvbiografi således: „Og her i den lille, smukke sønderjyske by har jeg fået et stille og hyggeligt hjem, hvor jeg hos disse to kære kan bo og nyde mit otium som pastor emeritus «. ${ }^{35}$ Ernst Kiørboe bevarede livet igennem det bedste og kærligste minde om sin far, som han agtede højt.

Måske søgte Ernst Kiørboe embedet i Tønder, fordi han lige som mange andre havde lyst til at komme ned og gore et arbejde for danskheden i det genvundne land. Der var i 1920'erne en kolossal interesse for Sønderjylland og for det vigtige arbejde blandt det danske flertal. Alene til embederne ved de fire nyoprettede statsskoler $\mathrm{i}$ Haderslev, Aabenraa, Sønderborg og Tønder indkom der i foråret 1920 over 200 ansøgninger! ${ }^{36}$

Man kan ikke udelukke, at Ernst Kiørboe kan være blevet opfordret til at søge det ene af de to (senere tre) lektorembeder, der skulle oprettes ved Tønder Statsskole pr. 1. august 1920. I marts 1920 var den 40-årige adjunkt ved Metropolitanskolen i København, Axel J. West, blevet udnævnt til rektor for Tønder Statsskole, og det blev en af den nye rektors forste opgaver at ansætte lærere til sin nye skole. West og Kiørboe kendte hinanden fra Sorø Akademi, hvor de sammen gik fra 1895 til 1898, da West blev student. De traf et par år senere igen hinanden på Københavns Universitet, hvor de begge studerede fransk. Hvad var mere nærliggende for en nyudnævnt rektor end at kontakte en gammel skolekammerat, studiekammerat og kollega, hvis faglige kvalifikationer var aldeles indiskutable, og prøve at få ham overtalt til at komme med til Tønder? Det kan naturligvis kun blive gisninger, men det er bemærkelsesværdigt, at da embederne ved de fire nyoprettede statsskoler i Sønderjylland blev opslået den 2 . marts 1920, re- 
agerede Ernst Kiørboe ikke, men søgte først til Sønderjylland, da stillingerne blev genopslået den 15. maj 1920, altså efter at West var blevet udnævnt til rektor i Tønder. Og Kiørboe søgte ikke som størstedelen af de øvrige ansøgere om at måtte komme $\mathrm{i}$ betragtning ved besættelsen af et af embederne ved en af de fire statsskoler, nej, den 22 . maj 1920 søgte han et lektorat ved statsskolen i Tønder. ${ }^{37}$

$\mathrm{Vi}$ ved, at rektor West kraftigt opfordrede Andreas Egeberg Jensen til at tage med til Tønder. Egeberg Jensen og West kendte hinanden fra Sorø Akademi, hvor de var kolleger fra 1915 og tre år frem, til West i 1918 fik embede på Metropolitanskolen i København. Egeberg Jensen blev i 1920 ansat i det andet af de tre lektorembeder ved Tønder Statsskole. Egeberg Jensen søgte, lige som Kiørboe, også først lektorstillingen ved Tønder Statsskole ved genopslaget i maj 1920.38

Der er ingen grund til at tro, at Ernst Kiørboe søgte til Tønder udelukkende af økonomiske årsager, men det ligger dog fast, at embedet i Tønder indebar nogle økonomiske fordele for ham. For det første var der et klækkeligt stedtillæg, og for det andet steg grundlønnen betydeligt, idet Kiørboe nu blev lektor. Årslønnen for de nyudnævnte lektorer ved Tønder Statsskole blev i sommeren 1920 af undervisningsministeriet og finansministeriet fastsat til kr. 7.527.39

\section{Mødet med Tønder}

Indtil 1920 var Tønder en lille, for de fleste ukendt, slesvigsk provinsby, som lå i en fjern afkrog af det store tyske rige. Efter Genforeningen blev Tønder Danmarks yderste grænseby helt nede i det sydvestlige hjørne af landet. Der var lang vej derned. Først en uendelig togrejse, og derefter lang ventetid i Tinglev, før rejsen ud til byen $i$ det flade marskland kunne begynde. Som en fattig trøst sagde man $i$ 1920'erne, at den tid man tilbragte i den dengang så triste ventesal på banegården i Tinglev, den ville blive trukket fra i skærsilden $!^{40}$

Den 19. juni 1920 modtog Ernst Kiørboe sin udnævnelse til midlertidig lektor ved Tønder Statsskole pr. 1. august s.å. Han blev ikke fastansat med det samme, men konstitueret i stillingen, idet der for alle lærerne ved de sønderjyske statsskoler var en prøvetid. I februar 1921 spurgte ministeriet rektor, om lærerne ønskede - og om rektor kunne anbefale - fastansættelse pr. 1. juni 1921. Rektor svarede bekræftende, men i en skrivelse til ministeriet den 25. februar 1921 påpegede Ernst Kiørboe imidlertid på lærerkollegiets vegne, at ministe- 

meraftenlys op til torvet, hvor der var markedsfest med boder og telte og laterner; folk talte et sprog, eller rettere to-tre sprog, der lød fremmed i mine oren: man var i udlandet! Men den næste morgens klare dagslys viste noget meget mere hjemligt $i$ den ganske vist særprægede, men væsentligt danske byggestil, den hjertelige modtagelse af de "gode danske", til hvem jeg var blevet henvist, og deres gode jyske mål; deres hyggelige hjem, deres glade smil og deres lune, når de fortalte om stedlige forhold og personer, alt sammen gjorde, at man meget snart følte sig hjemme og tryg ... Mit næste besøg var under genforeningsfestlighederne; vi var indkaldt til et første lærermøde, dagen før kongen skulle besøge Tønder. ${ }^{42}$ Det var vanskeligt at få soveplads, da hotellerne var optaget; men rektor West havde skaffet mig plads på en lille gæstgivergård "Sønderjylland «, der ikke mere eksisterer. Om aftenen, da jeg skulle i seng, blev jeg lidt forundret over at finde, at der allerede lå gæster i 3 af de 4 senge, som var stillet op i det lille værelse. De to af dem viste sig at være kolleger; den ene af dem var Rosenkjær, og det var altså mit første møde med ham. Hele natten hørte vi genforeningslystighed nede fra beværtningen og sange $i$ massevis, og når de danske slap op, tyede man til tyske. Næste morgen, da vi kiggede ned i den lille lukkede gårdsplads, så vi, at den var fyldt med gode danske Carlsberg og Tuborg flasker - tomme! ...«. ${ }^{43}$

Først var det tanken, at Tønder Statsskole skulle være en dansk realskole, men der var i befolkningen et stærkt ønske om et dansk gymnasium, og i maj 1920 gav undervisningsministeriet tilladelse til oprettelsen af et nysprogligt gymnasium. 1. juni 1920 ophørte den tyske realskoles undervisning, og den danske Tønder Statsskole overtog bygninger og grund. Dagen efter begyndte reparationsarbejderne, så Tønder Statsskole kunne stå klar til den fastsatte åbningsdag, den 25. august 1920. Tønder Statsskoles elevtal var da 126, fordelt på 8 klasser, nemlig 2 forberedelsesklasser, 1.-4. mellemskoleklasse, realklasse og 1. gymnasieklasse. Ud over rektor var der pr. 1 . august 1920 ansat 12 lærere: 3 lektorer, 7 adjunkter, 1 mellemskolelærer og 1 mellemskolelærerinde. I årets løb voksede elevtallet fra 126 til 205, og der blev pr. 1. oktober 1920 ansat yderligere en adjunkt samt en timelærer.4

Ingen af de lærere, elever eller forældre, der deltog i festlighederne i anledning af åbningen af Tønder Statsskole den 25. august 1920, glemte nogensinde den dag. 
Margrete Schultz, der begyndte i Ig i august 1920, og som senere, i 1923 , blev den første danske student i Tønder, fortæller følgende om den 25. august: "Den 25. august ... blev en meget stor dag for mig. Genforeningens rus, den store forandring i mit daglige liv - intet kunne måle sig med den følelse, der fyldte mig, da jeg som elev i Ig for første gang stod i skolens festsal. Jeg husker ikke de taler, der selvfølgelig blev holdt af rektor A. J. West, af amtmanden, grev Schack og sikkert flere. Jeg husker kun, at vi sang Grundtvigs dejlige salme: »Den signede dag med fryd vi ser fra havet til os opkomme, det lysner på himlen mer og mer, os alle til lyst og fromme, det kendes på os som lysets børn, at natten hun er nu omme“. Det var den dag ikke kun en salme, og sidste vers var som en verdslig jubelsang: "Så rejse vi til vort fædreland, der ligger ej dag i dvale ... så frydelig der til evig tid med venner $i$ lys vi tale«. Jeg har jo sunget den så mange gange, men den har aldrig tabt sin jubeltone for mig ... «. ${ }^{45}$

For samtlige lærere og elever, der var med fra begyndelsen, kom de første år til at stå i en særlig glans. Aldrig i skolens historie er der blevet arbejdet med større lyst og energi, end da skolen blev grundlagt.

I sine erindringer fra Tønder fortæller Margrete Schultz også lidt om den første tid på statsskolen: »Da vi var så få, fik vi et sjovt lille klasseværelse, der lå helt for sig selv. Det havde hørt til pedellens lejlighed og havde en lille entré. Vi sad omkring et stort bord, tre piger og tre drenge; jeg var den eneste fra Tønder, de andre kom fra oplandet med tog ... Når det store frikvarter nærmede sig, sivede der en dejlig kaffeduft op fra pedellens køkken i kælderen. Vi var som alle sønderjyder meget kaffeglade, og en skønne dag mødte jeg op på rektors kontor for at spørge, om vi ikke også måtte få kaffe. Det blev sandelig tilladt. Jeg tror ikke, vi betalte noget for den. Når 3. time var ved at være forbi, lød der en hyggelig klirren fra vores entré, det var pedellens kone med vores kaffebakke. Somme tider inviterede vi en af vores to yndlingslærere, Egeberg eller Kiørboe. Så løb vi til bageren efter wienerbrød. Lærerne kom med deres madpakker, det var utrolig hyggeligt ... Lektor Kiørboe, som vi så op til og holdt af, kæmpede hårdt med de tre fag, han havde med os. Latinen gik det endda med, den var jo ny for os, men han sled med at forbedre den skrækkelige udtale i engelsk og fransk, som vi alle medbragte fra vores tidligere lærere. Vi måtte slide i det, men vi nød de år. Vi blev unægtelig også forkælet af næsten alle vore lærere, og vi levede vort eget stille liv i vor fjerne lille klasse ... «. ${ }^{46}$ 


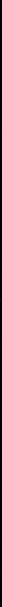

Tønder Statsskole 1920'erne. Eleverne søger efter ispinde på skolens fodselsdag.

Det første skoleår underviste Ernst Kiørboe i engelsk, fransk og latin i Ig, engelsk i mellemskolen samt engelsk i den ene af skolens to forberedelsesklasser. Det følgende skoleår fik han fransk i den nye Ig, og her fik han en ganske særlig elev, der var ca. dobbelt så gammel som alle de øvrige elever: Gwendolynne Kiørboe! Hun havde længe haft lyst til at lære fransk, og de gik derfor til rektor og fik dennes tilladelse til, at Gwendolynne kunne følge fransktimerne i Ig. Ikke mindst pigerne var meget begejstrede for deres søde med-elev. ${ }^{47}$

De mange lærere, og embedsmænd i øvrigt, der i 1920 kom nordfra til det genvundne land, havde alle fået besked på, at det ikke gjaldt om at skabe en ny Köller-politik ${ }^{48}$ med modsat fortegn, men at få arbejdet til at gå så gnidningsløst som overhovedet muligt. Der blev knyttet mange venskaber mellem de nye, som på kort tid fik en ganske stor omgangskreds. Dette gjaldt også familien Kiørboe, som hurtigt fik mange venner i Tonder trods det, at de $i$ august 1920 så at sige ingen kendte $\mathrm{i}$ byen og dens opland. En af de eneste, som $\mathrm{i}$ forvejen var dem bekendt i Sønderjylland, var den nyudnævnte dommer og senere tillige borgmester i Løgumkloster, H. H. Stegmann, som i 1937 blev udnævnt til dommer $\mathbf{i}$ Tønder. Han var en af Ernst Kiørboes gamle regenskammerater, og der blev nu rig lejlighed til at få bekendtskabet genopfrisket. Familien Kiørboe og familien Stegmann blev nært knyttet til hinanden resten af livet. 
Venskabet mellem Kiørboes og familien på Schackenborg i Møgeltønder, lensgreve og amtmand over Tønder amt 1920-49, O. D. Schack og hustru, bør også omtales. De to familier lærte ret tidligt hinanden at kende og beundrede gensidigt hinandens karakter, væsen og kultur, og på den baggrund opstod der et varmt venskab, som fik stor betydning for begge parter. Kiørboes var ofte gæster på Schackenborg, også overnattende gæster. De holdt jul på Schackenborg $\mathrm{i}$ årene 1938-40 og igen $\mathrm{i} 1942$, og de to familier fejrede i 1941 nytår sammen. I 1939 holdt Kiørboes en uges sommerferie på Schackenborg og i 1940 to ugers sommerferie. Også døtrene fra Schackenborg blev nært knyttet til Kiørboes. Ernst Kiørboe underviste dem i deres gymnasieår på Tønder Statsskole, og alle tre piger kom ofte på besøg i Havehuset i Carstensgade. Den ene af døtrene, Eva Schack, var meget musikalsk og havde en glimrende sangstemme, og Kiørboe akkompagnerede hende ofte, når hun optrådte. En anden af døtrene, Karin Birgitte Schack, holdt med lange breve, især til jul og til fødselsdag, forbindelsen med Ernst Kiørboe ved lige helt til hans død.

Desværre kom det $\mathrm{i}$ de sidste krigsår til et brud mellem Kiørboe og O. D. Schack. Forskelligt syn på, hvordan man efter krigen skulle sætte ind over for det tyske mindretal i Tønder, skabte modsætninger mellem en gruppe borgere, deriblandt Ernst Kiørboe, og O. D. Schack. Grev Schack havde igennem hele sin tid som amtmand undladt at deltage i politisk arbejde, idet han fandt det uforeneligt med stillingen som kongevalgt formand for et folkevalgt råd. Han havde dog aldrig lagt skjul på, at det var hans grundholdning, at de politiske dumheder, som det danske mindretal i Slesvig var udsat for af de tyske myndigheder mellem 1864 og 1920, ikke - med omvendt fortegn - måtte gentage sig efter genforeningen med Kongeriget. Den indstilling kunne ikke anfægtes, og den prægede i øvrigt Danmarks officielle politik i mellemkrigsårene. I 1943-44 blev det imidlertid klart for de fleste, hvorledes krigens udfald ville blive, og så ændrede stemningen sig gradvist i retning af et opgør med tyskerne. O.D. Schacks kone var af tysk afstamning, og på Schackenborg fik hun ofte besøg af slægtninge iført nazi-uniform. Det satte rygter i gang, og man påstod, at O. D. Schack sympatiserede med nazisterne. Det er der ikke belæg for, men rigtigt er det, at O. D. Schack ofte - også i 1943-45 - talte det tyske mindretals sag i forsøget på at skabe ro og fred i grænselandet. Grev Schack følte, at 
Ernst Kiørboe lod sig rende omkuld af de sidste krigsårs letkøbte stemninger. O. D. Schack døde $\mathbf{i}$ januar 1949, uden at en forsoning mellem de to familier havde fundet sted. ${ }^{49}$

\section{Gymnasielæreren}

Det er blevet sagt - og utvivlsomt med rette - at Ernst Kiørboe var aldeles suveræn i sin beherskelse af de tre sprog, han underviste i. En tidligere elev og senere kollega, Chr. Kastberg Nielsen, har udtalt følgende om Kiørboes sproglige færdigheder: "Han ville have kunnet lære engelske engelsklærere engelsk, og latin læste han så selvfølgeligt som en skolastiker «. ${ }^{50}$ Sådan ønskede Kiørboe også selv, det skulle være, og allerede i sin studietid på Københavns Universitet blev det klart for ham, hvor vigtigt det var, at han var i stand til at tale sine sprog fuldstændig korrekt og helt uden accent.

Den 28. februar 1905 skriver stud.mag. Ernst Kiørboe i et brev til sin far: »Kære far. Jeg har endnu kun tid til et jasket brev; jeg har nemlig en ting, som jeg ville spørge dig om. Det er, om jeg må gennemgå et kursus på Berlitz School for at lære at tale og skrive engelsk. Som du måske ved, er disciplinen sprogfærdighed dobbeltkarakter til eksamen, altså et vigtigt fag, og jeg tror ikke, det vil lykkes mig, alene ved at læse engelske bøger og følge øvelser i engelsk stil o.s.v., at lære det så godt, som jeg gerne ville og skulle. Man plejer gerne at gøre noget $\mathrm{i}$ den retning: nogle har manduktør, andre har måske udenlandske bekendtskaber her $\mathrm{i}$ byen, andre har måske haft en eller anden lejlighed til at rejse til det pågældende land, f.eks. til såkaldte feriekursus, som holdes både i England og Frankrig. - Hvor meget et kursus i Berlitz School vil gavne, ved jeg jo ikke, men jeg tror, at når man kan så meget af et sprog, som jeg dog kan af fransk og engelsk, så vil selve det at tale en time med en indfødt et par timer om ugen være gavnligt. - Jeg har aftalt med en kammerat at læse, hvis jeg måtte for dig. Et kursus på ca. 3 måneder (30 timer) koster $36 \mathrm{kr}$. pro persona, når man er to ...«. ${ }^{51}$

Om Ernst Kiørboe har fået lov til at følge det nævnte kursus på Berlitz School, vides ikke, men ved bifagseksamen i engelsk i juni 1906 opnåede han i sprogfærdighed karakteren $\mathrm{mg} \div$, efter vore dages karakterskala lig med 8, og ved hovedfagseksamen i fransk i januar 1908 fik han mg i sprogfærdighed, svarende til et 9-tal i dag. ${ }^{52} \mathrm{Da}$ han $\mathrm{i}$ forsommeren 1911 ankom til New York og indfandt sig hos 

det engelsktalende Amerikas vigtigste politiske institutioner samt dets sociale forhold i nutiden. Ernst Kiørboe anførte videre, at han ved besøg på amerikanske skoler og universiteter ønskede at fortsætte sine studier af Amerikas højere skolevæsen. Før ansøgningens videresendelse til ministeriet skulle den påtegnes af rektor West, som varmt anbefalede, at den blev imødekommet. Den 5 . januar 1923 svarede ministeriet, at den ansøgte orlov blev bevilget under forudsætning af, at Ernst Kiørboes timer kunne blive besørget på tilfredsstillende måde. ${ }^{54}$

Primo september 1927 søgte Kiørboe undervisningsministeriet om en måneds orlov $i$ forlængelse af juleferien, 6. januar-6. februar 1928, til en rejse til Frankrig. Formålet med rejsen var vedligeholdelse og fornyelse af den praktiske færdighed i brugen af talesproget. Ernst Kiørboe anførte, at han ikke siden 1908 havde været $i$ Frankrig uden for sommerferien, og at han ville være meget interesseret $\mathrm{i}$ at se skoler $\mathrm{i}$ virksomhed, hvorfor han havde overvejet muligheden for at søge orlov i løbet af skoleåret. Kiørboe ansøgte desuden ministeriet om at lette ham udgifterne til vikar, da det var en studierejse, han søgte orlov til. Skolens rektor anbefalede, at ministeriet så velvilligt på ansøgningen, også den sidste del om betaling af vikarudgifterne. Den 10. november 1927 meddelte ministeriet, at den ansøgte orlov var bevilget, men at Kiørboe selv måtte betale vikarudgifterne. Til hjælp bevilgede ministeriet ham dog kr. 300. Da der var tale om ca. 135 timer til en timeløn på 3,16 kr., var det trods alt størstedelen af vikarudgifterne, ministeriet betalte. $^{55}$

Et par enkelte år havde Ernst Kiørboe ingen timer i latin, og i skoleåret 1949/50 havde han ingen timer $\mathrm{i}$ fransk, men ellers underviste han hvert år i alle sine tre eksamensfag, hovedsageligt i gymnasiet, men også med enkelte timer i realklassen og/eller mellemskolen. Det vil nok svimle for de fleste gymnasielærere af $\mathrm{i}$ dag, når de bliver konfronteret med en gymnasielærers fagfordeling i 1920'erne og 30'erne. I skoleåret 1931/32 så Ernst Kiørboes fagfordeling således ud: Engelsk i IIIg (5), IIg (5), 2. mellem (5). Fransk i IIIg (4), IIg (4), Ig (4). Latin i IIIg (3). Sang i Ig, IIg, og IIIg (1). I alt 31 ugentlige undervisningstimer. ${ }^{56}$

Bemærk, at Kiørboe havde både engelsk, fransk og latin i IIIg, og at han i øvrigt i dette skoleår - for første og eneste gang - underviste i sang, nemlig en ugentlig fællessangtime med musikorientering med 
alle tre gymnasieklassers ca. 40 elever. Selv om arbejdsbyrden har været betydelig, kan man naturligvis ikke - alene ud fra det ugentlige antal undervisningstimer - sammenligne den med i dag.

Alt tyder på, at Kiørboe befandt sig godt i Tønder. Når han alligevel adskillige gange søgte væk, var det ikke, fordi han nødvendigvis ønskede at forlade Tønder, men fordi han ønskede et avancement. Efter syv år ved Tønder Statsskole, i juni 1927, begyndte han at søge rektorembeder, i dette tilfælde ved Svendborg Statsskole. I maj 1929 søgte han rektorembedet ved den skole, hvor han fra 1918-20 havde været ansat som adjunkt, nemlig Kolding højere Almenskole, i juni 1930 søgte han Nykøbing Katedralskole på Falster, i marts 1934 Herlufsholm Skole og i juni 1937 Odense Katedralskole. ${ }^{57}$

Ernst Kiørboe har efter al sandsynlighed søgt flere rektorembeder end de her nævnte, men på Rigsarkivet er undervisningsministeriets protokoller over ansøgere til embeder ved statens højere skoler i tidsrummet 1940-57 desværre bortkommet, så det er svært at fastslå det med sikkerhed. I 1942 udtalte han imidlertid til skolens elevblad, "Guldhornet«: "... Ved Tønder Statsskole har jeg haft min længste virketid, og det ser mest ud til, at Tønder Statsskole bliver min sidste arbejdsplads ... «. $^{58}$ Helt sikker var han altså ikke! Bag de citerede udtalelser kunne godt ligge, at han også i begyndelsen af 1940'erne havde en eller flere ansøgninger om rektorembeder liggende i ministeriet.

Man kan så spørge, hvorfor Ernst Kiørboe hver gang blev vraget, når rektorembederne skulle besættes, trods det, at der på det tidspunkt gennemsnitligt kun var 10-15 ansøgere til hvert rektorembede. Praksis vedrørende ansøgning om rektorembeder ved statens højere skoler samt kommunale almenskoler var således: Ansøgerne stilede deres ansøgning til kongen og sendte den til undervisningsministeren. Ved ansøgningsfristens udløb sendte undervisningsministeriet de indkomne ansøgninger til undervisningsinspektøren for gymnasieskolerne med anmodning om en vurdering af ansøgernes egnethed som rektor samt en udtalelse om, hvem han anså for den bedst egnede. Når undervisningsinspektørens udtalelser forelå, indstillede undervisningsministeren derefter til kongen, at den af undervisningsinspektøren foreslåede kandidat blev udnævnt. Der findes mig bekendt ikke fra disse år et eneste eksempel på, at ministeren $i k k e$ fulgte undervisningsinspektørens indstilling, så det var altså i realiteten undervisningsinspektøren for gymnasieskolerne, der afgjorde sagen. Når det aldrig lykkedes Ernst Kiørboe at komme i betragtning ved 


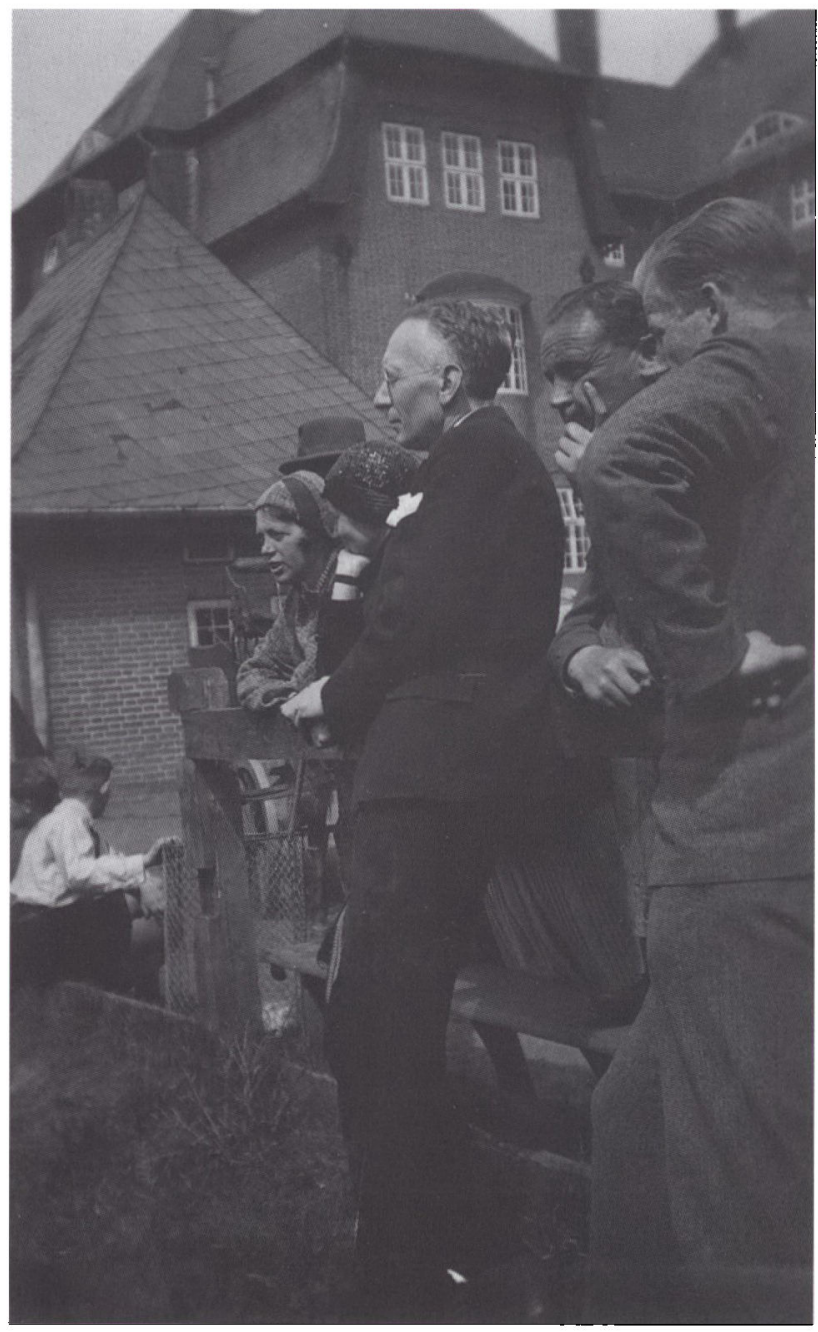

Gymnasielærere betragter eleverne ved skolens fodselsdag. I midten lektor Kiarboe, til højre for ham Aage Rosenkjar. Foto $i$ Lokalhistorisk Arkiv for Tonder kommune.

besættelsen af et rektorembede, kunne man med god grund tro, at det var, fordi undervisningsinspektøren ikke fandt Kiørboe egnet som rektor. Det er imidlertid forkert! I sin vurdering af ansøgerne til rektorembedet ved Kolding højere Almenskole i juni 1929, skriver undervisningsinspektøren om Ernst Kiørboe, at han (undervisningsinspektøren) er overbevist om, at lektor Kiørboe er et rektoremne, og at han fuldt ud kan tiltræde de rosende udtalelser om ham af rektorerne Bruun og West. ${ }^{59}$ I tilfældet Kolding højere Almenskole var der imid- 
lertid en ansøger, som undervisningsinspektøren fandt endnu bedre egnet end Kiørboe, og sådan kan det muligvis også have været for alle de øvrige stillingers vedkommende.

Spørgsmålet er imidlertid, om Ernst Kiørboe ikke i realiteten har spændt ben for sig selv og dermed $i$ en vis grad selv ødelagt sine chancer for at blive rektor. I hvert fald kan man ikke lade være med at undre sig grundigt over hans ansøgninger, som er bemærkelsesværdigt kortfattede. Mens de øvrige ansøgere vender hver en sten for at vise deres fortræffeligheder, er Ernst Kiørboes ansøgninger yderst beskedne i omfang. Og der er desuden ingen tvivl om, at den lille autentiske historie (se side 125f) om Ernst Kiørboe og den ministerielle fagkonsulent har nået undervisningsinspektørens skrivebord, og den historie kan umuligt have styrket Kiørboes muligheder for at blive rektor. Det er blevet sagt om Ernst Kiørboe, at han var aldeles upåvirket af direktorale love og profeter. ${ }^{60}$ Måske heller ikke lige, hvad man venter af en ansøger til et rektorat! Til dette sidste må dog retfærdigvis nævnes, at Kiørboe gennem alle årene på Tønder Statsskole var rektors stedfortræder. Når rektor var syg, var på tjenesterejse, eller havde orlov, var det hver gang Kiørboe, der var fungerende rektor, et hverv som han bestred til alles fulde tilfredshed.

I juni 1945 indstillede skolens rektor, Jakob Randrup, til undervisningsministeriet, at lektorerne Kiørboe og Kondrup måtte blive dekoreret. Rektor fandt, at 25 -året for Genforeningen var en glimrende lejlighed til at dekorere disse to lærere, der havde været med i arbejdet på Tønder Statsskole igennem alle 25 år. Det viste sig imidlertid, at der netop i 25-året for Genforeningen var ekstraordinært mange dekoreringer, så ministeriet henlagde rektors indstilling og satte midlertidigt sagen $\mathrm{i}$ bero.

30. oktober 1947 skrev rektor atter til undervisningsministeriet og mindede om sin henvendelse fra juni 1945. Ministeriet forhørte sig nu hos undervisningsinspektøren for gymnasieskolerne, som den 15. marts 1948 anbefalede, at indstillingen om at dekorere de to lektorer blev fulgt.

Den 19. april 1948 indstillede chefen for undervisningsministeriets 2. departement til kabinetssekretæren, at E. A. Kiørboe og K. R. Kondrup blev udnævnt til Riddere af Dannebrog. Om Ernst Kiørboe skriver departementschef Paludan-Müller i sin indstilling:

»Lektor ved Tønder Statsskole Ernst August Kiørboe ... ansattes i 1918 som adjunkt ved Kolding højere Almenskole. Ved kgl. resolution 


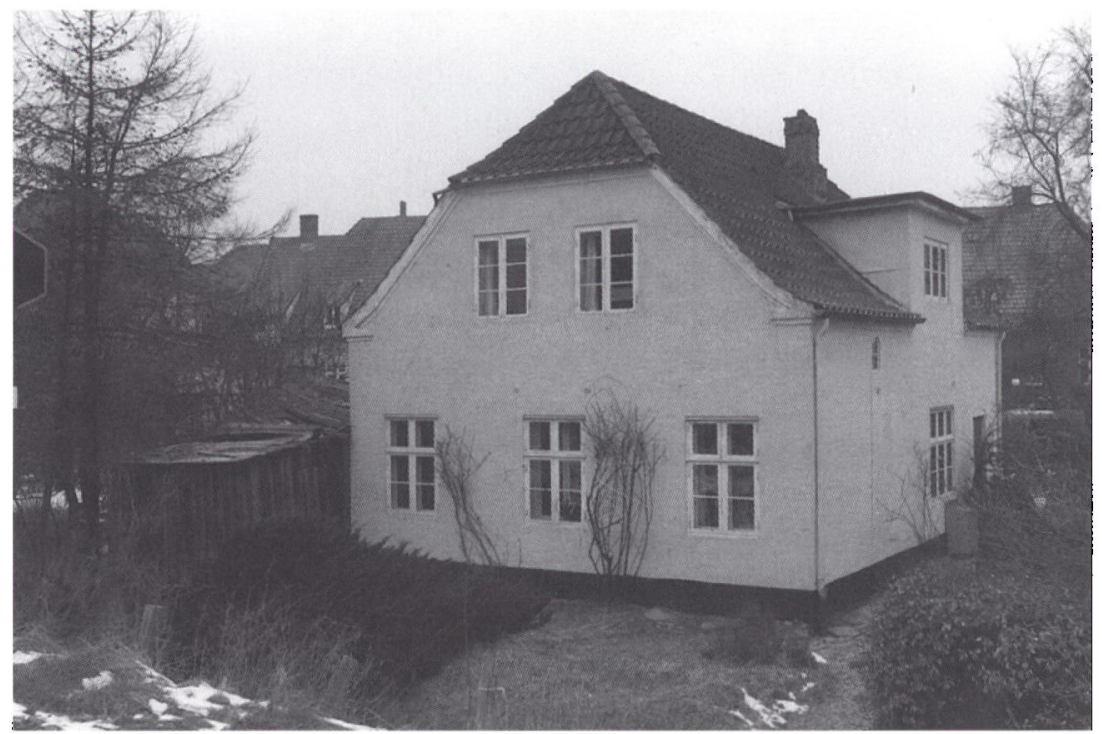

Kiørboes bolig, havehuset $i$ Carstensgade 11, hvor familien lejede sig ind $i 1925$. Oprindelig havde huset varet en stald, men var siden lavet om til et havehus. Efter 1925 blev det helt ombygget efter Kiorboe-familiens egne onsker. Det blev udvidet med en ekstra etage, bl.a. for at fá rigelig plads til Ernst Kiørboes far, som efter pensioneringen var flyttet til Tonder. Foto: Lars Kiørboe 1981.

af 1. juni 1921 blev han udnævnt til lektor ved Tønder Statsskole, hvor han siden har haft sin embedsgerning. Lektor Kiørboe er en særdeles dygtig lærer, der igennem alle årene har været skolen en udmærket støtte. Han har gennem sin rige og fine menneskelighed formået at knytte eleverne til sig og har stedse stået $i$ det bedste forhold til skolens forældrekreds «.61

Det kan undre, at Kiørboes melodi til den vestslesvigske hjemstavnssang og sangens betydning for Sønderjylland slet ikke omtales $i$ indstillingen.

Den 14. maj 1948 udnæuntes Kiørboe og Kondrup til Riddere af Dannebrog. Alle personer, der bliver dekoreret, opfordres til at indgive en levnedsberetning til Ordenskapitlet på Amalienborg Slot. Kiørboe fulgte ikke denne opfordring og sendte aldrig Ordenskapitlet en sådan beretning.

Ernst Kiørboe deltog aldrig som foredragsholder eller igangsætter i det folkelige arbejde på vesteregnen, og han var ikke som mange af sine kolleger, fx Egeberg Jensen, Rosenkjær og Johan Larsen til daglig 
med i skolens fritidsarbejde, hverken i skolens start i 1920'erne eller sidenhen. Dog bør Kiørboes medvirken bag klaveret ved skoleteaterforestillinger og ved skolekoncerter nævnes. Her var han altid villig til at være med, og her ydede han gennem årene en fortjenstfuld indsats som klaverakkompagnatør.

Hvad det var ved lærergerningen, Ernst Kiørboe fandt inspirerende, hvad der var den dybeste impuls for ham i arbejdet, har han aldrig fortalt.

I Chr. Kastberg Nielsens fremragende portræt af ham i skolens årsskrift 1981 kommer vi dog personen Ernst Kiørboe lidt nærmere. Her fortæller Kastberg Nielsen bl.a. om Kiørboes anderledeshed som lærer: "Anderledes var han ... fordi ... han var ab-solut, uafhængig, fri af sine elever: lysets børn eller mørkets, redebonne ånder eller nothing but body, opmærksomme eller uopmærksomme - ham der var opmærksomheden selv in persona, autonom opmærksomhed, ham kunne de ikke anfægte. Til gengæld anerkendte han deres absolutte ret til at motivere sig selv og til evt. at forblive delvis eller helt umotiverede. For den synligt ubevægede, nærmest fraværende elev, der - fredeligt adspurgt: "Søster, hvad sidder du og tænker på?« lige så fredeligt svarede: " $Æ$ sidder og tænker $o$, at nu er der kun fire timer til æklok er to« - for hende havde han den fuldeste forståelse ${ }^{62}$

Der var delte meninger om ham blandt eleverne. Specielt elsket eller populær var han ikke, men hans faglige ekspertise indgød stor respekt, og for den måtte de alle bøje sig! ${ }^{63}$

Fhv. landsarkivar Peter Kr. Iversen, Aabenraa, fandt Kiørboes undervisning gammeldags og husker endnu hans sorte notesbog, hvori han dag efter dag noterede elevernes præstationer. Iversen nævner dog, at hans lidt anstrengte forhold til Kiørboe meget vel kan skyldes egne begrænsede sproglige anlæg, og at han kun gik i nysprogligt gymnasium, fordi der endnu ikke var oprettet matematisk linie. Peter Kr. Iversen fortæller også den lille, autentiske historie, som jeg tillige har hørt fra en række andre personer, om Kiørboe og den nyligt udnævnte ministerielle fagkonsulent, der en dag kom på besøg på Tønder Statsskole og gerne ville have lov til at overvære et par timer hos lektor Kiørboe. Da fagkonsulenten senere på dagen skulle tage afsked med Kiørboe, sagde han skånsomt og venligt, at man nu til dags $i$ sprogundervisningen var begyndt at gøre tingene lidt anderledes end før $\mathrm{i}$ tiden. I sine egne 

Kiørboe knyttede nogen videre udlægning til dem, ud over nødvendige kommentarer. Når jeg endnu så mange år efter kan citere strofer fra disse digte, er det vel, fordi han lod dem klinge og tale for sig selv, når vi fremsagde dem under hans kyndige vejledning “ 65

Der blev i tidens løb - og tid var der nok af: Han blev over 98 år - hæftet mange adjektiver på personen Ernst Kiørboe: Nogle Kastberg Nielsen kalder dem "skumlerne" - fandt ham, og ikke helt uden gode grunde, arrogant, men ellers er det ord som fornem, fin, aristokratisk og stilfuld, der bliver brugt som karakteristik. Da rektor Randrup i 1937 tjenstligt skulle påtegne og videresende hans ansøgning om rektorstillingen ved Odense Katedralskole, påpegede han, at »lektor Kiørboe er en højt kultiveret og fint dannet personlighed $"$, og at Kiørboe »ved hele sin noble færd vinder agtelse hos alle ${ }^{66}$

\section{Pensionist}

Den 11. februar 1953 fyldte Ernst Kiørboe 70 år. Allerede den 7. januar 1953 havde han ansøgt ministeriet om afsked p.g.a. alder fra udgangen af februar 1953. Han tilføjede dog i ansøgningen, at han var rede til at fortsætte skoleåret ud, hvis ministeriet ønskede det. Rektor anbefalede kraftigt, at Kiørboe måtte fortsætte med at undervise resten af skoleåret, idet han både havde engelsk, fransk og latin i IIIg. Den 28. januar meddelte ministeriet Kiørboe afsked p.g.a. alder i nåde og med pension fra 31. juli 1953 at regne ${ }^{67}$.

Ved morgensangen på fødselsdagen den 11. februar lykønskede rektor ham med de 70 år og takkede ham for hans arbejde ved skolen siden dens oprettelse.

Den 4. marts om aftenen fejrede elevforeningen ham. Til stede var forældre, lærere og gamle og nuværende elever. Man indledte naturligvis med at synge For en fremmed barsk og fattigt, og hovedtalen blev holdt af en af Kiørboes gamle elever, læge Harald Jensen, Aalestrup. Han formede sin tale som en personlig tak, og mange andre af de tidligere elever tog ordet, nogle af dem på sønderjysk, og takkede hr. og fru Kiørboe. Aftenen blev ud over en hyldest til Kiørboe også en hyldest til skolen, og det blev fremhævet, at den bedste genforeningsgave til Sønderjylland var den danske skole. Også rektor bragte en hyldest til Ernst Kiørboe, og til sidst udnævnte elevforeningens formand ham til æresmedlem af elevforeningen. ${ }^{68}$ 
Ved translokationen i juni takkede rektor endnu engang Ernst Kiørboe og sagde bl.a.: "... Lektor Kiørboe har holdt af Tønder Statsskole, og Tønder Statsskole har holdt af ham. Det har været en lykke for skolen, at mennesket Ernst Kiørboe har været knyttet til den i 33 år ...«, og formanden for elevforeningen ønskede ham med tak for hans rolige og dybtgående undervisning et godt otium med megen lejlighed til at dyrke de mange interesser, der optog ham. ${ }^{69}$

Men Tønder Statsskole slap ham nu ikke sådan uden videre! Aldrig så snart var han blevet pensioneret, før han, bl.a. under kollegers sygdom, blev bedt om at påtage sig vikariater, og hver eneste gang stillede han sig til rådighed.

Der er ingen tegn på, at disse vikariater føltes som en byrde for ham, måske har han ligefrem fundet det hyggeligt lejlighedsvist at gense sin gamle skole. Men det bør dog ikke forties, at han følte sig fremmed over for den moderne skole. En skole, hvor alle skranker er blevet brudt, hvor læreren ikke længere er den docerende, hvor eleverne har medbestemmelsesret og til dels arbejder på lige fod med læreren, en skole hvor undervisningen i højere grad skal være underholdende end kundskabsmeddelende og kvalitativ, for den skole havde han kun hovedrysten tilovers.

At han som lærer var anderledes end vore dages lærere, ligesom eleverne naturligvis var anderledes end vore dages elever, kan ikke undre. Han kunne fx ikke duplikere, fotokopiere, båndoptage, ja, han kunne såmænd nok ikke engang skrive på maskine. Han var ikke medlem af et hav af samarbejdsudvalg, og han var ikke gruppearbejder eller elevvenlig elevkammerat. End ikke en toptåbe kunne i fuldskab have fundet på at sige »du« og »Ernst« - Når nogle talte til ham om »Deres gamle skole«, erklærede han afvisende: "Den er ikke min skole! «. ${ }^{70}$

Hvad angår tiltaleformer fortælles følgende samtale, som i 1970'erne udspandt sig mellem Ernst Kiørboe og den gode hushjælp: "Sig mig, fru Nielsen, er det nu blevet normalt, at man siger "du« til folk? Både i banken og på rådhuset sagde de »du« til mig, og uden at jeg bad dem om det! - »Ja, det er vist ved at blive normalt! « "Skal vi to så også til at være dus? « - "Det behøves ikke. Det fungerer udmærket, som det hele tiden har gjort! «. ${ }^{71}$

Ernst Kiørboe komponerede andet end melodien til For en fremmed barsk og fattigt, men intet af det eksisterer vist mere.

Ernst Kiørboe fik et sjældent langt og aktivt otium på hele 28 år, 
og han døde den 22. februar 1981, mere end 98 år gammel. Han blev bisat fra Kristkirken i Tønder den 28. februar. Da kisten blev båret ud, blev For en fremmed barsk og fattigt spillet. $^{72}$

Men den vestslesvigske hjemstavnssang fulgte ikke Kiørboe i graven. Den er stadig med i Højskolesangbogen og er stadig en af de mest sungne sange i Sønderjylland. På Tønder Statsskole - nu Tønder Gymnasium og HF - synges For en fremmed barsk og fattigt både første skoledag $i$ august og ved translokationen $i$ juni og indrammer således skoleåret.

\section{NOTER OG HENVISNINGER}

1. Andreas Egeberg Jensen, f. $31 / 7-1889$, t 25/3-1961, lektor v. Tønder Statsskole 1920-37.

2. SM 1988 s. 250.

3. VE.

4. Carl William Kiørboe, f. 26/9-1850, + 4/12-1930, 29/8-1877 med Susanne Sophie Elisabeth Henriette Laub, $f$. 8/6-1852, + 17/10-1897.

5. Thomas Linnemann Laub, f. 5/12$1852,+4 / 2-1927$.

6. SOB + K II s. 161 - Hardenack Otto Conrad Zinck, f. 2/7-1746, + 15/21832, 27/9-1774 med Susanne Elisabeth Pontet, der var af fransk herkomst, 1745-1832.

7. Frederik Vilhelm Kiørboe, f. 27/7$1878,+29 / 3-1952, \sim 10 / 6-1906$ med Anna Margrethe Lossl, f. 6/8-1888, $+29 / 8-1962$.

8. K II s. $166 \mathrm{ff}$.

9. K II s. 167.

10. Hardenack Otto Conrad Laub Kiørboe, f. 23/1-1880, + 21/9-1954, 17/ 5-1911 med Marie Madeleine Borchorst, f. 1/9-1884, + 26/2-1958.

11. SA + AAR - EAK afsluttede sit første skoleår på akademiet, 1895/96, som nr. 7 ud af 20 elever, $0 g$ han placerede sig ved de afsluttende årsprøver efter III klasse i foråret 1897 som nr. 7 ud af 23 elever.

12. Det Müllerske Legat blev oprettet i $1828 \mathrm{i}$ henhold til testamente efter distriktskirurg Heinuich Friedrich Müller fra Skælskor. Legatet uddeltes til kostelever, hvis fader var kongelig udnævnt tjenestemand. I dag (1995) uddeles legatet én gang årligt til tre eller fire kostelever, hvis fader/moder beklæder en stilling, der på fundatsens tid ville kræve en kongelig udnævnelse. Hver legatportion er $\mathrm{i}$ dag på kr. 2.000,-. Kilde: Brev af 28. marts 1995 fra Sorø Akademis rektor til artiklens forfatter.

13. BE.

14. $\mathrm{FO}+\mathrm{BE}-\mathrm{Et}$ par få gange opstod der uregelmæssigheder. Det drejer sig bl.a. om tobaksrygning, om boldspil på et tidspunkt, hvor det var forbudt at spille bold, og om en mindre forseelse forårsaget af kådhed; alt sammen noget, som i dag højst kan fremkalde en løftet pegefinger; men på Sorø Akademi i 1897 og 1898 var det alvorlige brud på skolens ordensreglement, og de omtalte forhold udvirkede både et tilfælde af husarrest og et tilfælde af havearrest samt i det følgende skoleår en nedsættelse af legatportionen med kr. 100.

15. AAR + BE - EAK placerede sig som nr. 4 ud af 22 elever. Det fine resultat fik bl.a. til følge, at han i skoleåret $1899 / 1900$ blev tildelt en legatportion af Det Müllerske Legat på hele 400 kr., det højeste beløb der indtil da nogensinde var blevet tildelt en elev på Soro Akademi.

16. EP.

17. K II s. $170+\mathrm{PR}$.

18. BE.

19. PO.

20. K III s. 86.

21. FI - EAK er oppe til filosofikum den 
7. juni 1901 og består med karakteren mg.

22. K III s. 87.

23. $\mathrm{OS}+\mathrm{SE}+\mathrm{BR}$.

24. CA - Det er muligt, at EAK vender tilbage til koret i 1904. Der er dog ikke fundet bevis herpå i Cæcilia-foreningens arkiv, men arkivet er meget stort og uregistreret, og noder, breve, protokoller m.m.m. ligger - med arkivar Knud Andersens ord - whulter til bulter mellem hinanden«. Arkivet er derfor meget vanskeligt at arbejde med, og det har kun været muligt at finde EAKs navn i protokollerne fra $1900-$ 1903, men en effektiv søgning har som nævnt ikke været mulig.

25. Henrik Knudsen 1873-1946. Han var gennem en menneskealder blandt Det kgl. danske Musikkonservatoriums mest ansete lærere.

26. Ditlev Christian Ernst Laub, f. 11/61847, + 30/11-1919, 14/5-1883 med Cathrine Ann Gaynor, f. 26/7-1856, + 23/9-1914.

27. Gwendolynne Petra Laub, f. 22/8$1889,+27 / 7-1974$.

28. FK - Ved begyndelsen af skoleåret 1908/09 sluttedes Diackers Kursus, Undervisningsanstalten Kobenhavn (senere Kursus Kobenhavn), Lang og Hjorts Kursus og Wedels Kursus sammen $i$ en institution, der havde et okonomisk samarbejde, men hvor de enkelte kursus i pæedagogisk henseende fuldt ud bevarede deres selvstændighed. Institutionen, der gik under navnet "De forenede Kursus", blev i 1909/10 udvidet med eksamenskurset Lykeion. De forenede Kursus oplostes i 1921, hvorefter kurset blev en offentlig institution under navnet "Statens og Hovedstadskommunernes Kursus".

29. K III s. $87 f$.

30. FK + JU III s. 208 - Det har ikke været muligt at få ansættelsen på Københavns Translatørskole bekræftet, idet det indtil videre ikke er lykkedes mig at finde frem til Københavns Translatørskoles arkiv. Ifølge den her anvendte kilde varede ansættelsen ved Kobenhavns Translatørskole til 1918.

31. AN.

32. K II s. 178.
33. SK.

34. JO 2. dept. $271 / 20$.

35. K II s. 179.

36. GR.

37. JO 2. dept $271 / 20$.

38. GR + JU II s. 73.

39. JO 2. dept. $566 / 20$.

40. JL s. 6.

41. JO 2. dept. $566 / 20+$ LØ.

42. Det er usikkert, om EAK husker rigtigt her. I hvert fald anfører Egeberg Jensen $i$ jubilæumsbogen "Tonder Statsskole 1920-35«, at han for forste gang ankom til Tonder den 12 . juli, samme dag som kongen havde besøgt byen, idet det nye lærerkorps dagen efter var indkaldt til det første mode.

43. JU II s. 88f.

44. JU III s. 4 + JU IV s. $49 f$. + TSAA 1921 s. $12 \mathrm{f}$. $+\mathrm{CE}$.

45. SAA 1987 s. 157.

46. SAA 1987 s. 158.

47. FA + SSG s. 33.

48. Efter Ernst M. von Köller (1841-1928), preussisk embedsmand og politiker, der som overpræsident i Slesvig-Holsten 1897-1901 med hård hånd forsøgte at bekæmpe danskheden.

49. ODS + K III s. 91 + brev af 14/8-1997 fra lensgreve Hans Schack og brev af s.d. fra Eva Zachariae, f. Schack.

50. TSAA 1981 s. 47.

51. PA AI,1. Pk. 1.

52. SE.

53. K III s. 88.

54. JO 2. dept. $1060 / 22+$ KO 2. dept. $192-94 / 23$.

55. JO 2. dept. $595 / 27+\mathrm{KO} 2$. dept. 17569-70/27.

56. FA + TSAA 1920-53.

57. JO 2. dept. 1. kt. 403/27, 354/29, 378/ $30,467 / 37$ + brev af 16/9-1997 fra Herlufsholm Skoles arkivar, lektor Lars Bardram.

58. GU s. 346.

59. JO 2. dept. 1. kt. 354/29.

60. TSAA 1981 s. 48.

61. JO 2. dept. 1. kt. $10-1 / 45+$ KO 2 . dept. 1. kt. 8394/ 48 .

62. TSAA 1981 s. $47 \mathrm{f}$.

63. TSAA 1981 s. 47.

64. Historien er bl.a. omtalt $i$ brev af $5 / 2-$ 1997 fra P. Kr. Iversen og nævnt i TSAA 1981 s. 48 samt meddelt mig 
telefonisk af Birgitte Hegtmann, f. Stegmann, august 1997.

65. Brev af 12/5-1996 fra Herman Pump.

66. TSAA 1981 s. 50 f. + JO 2. dept. $467 /$ 37.

67. JO 2. dept. 1. kt. 143/53.

68. GU s. $745 f$.

69. GU s. 746.

70. TSAA 1981 s. $46 f$.

71. Brev af 13/8-1997 fra Edith Nielsen.

72. Brev af 10/3-1997 fra Inger Kiørboe.

\section{LITTERATURLISTE OG KILDEFORTEGNELSE}

Forkortelser:

$\mathrm{KB}=$ Det kongelige Bibliotek i København

$\mathrm{KS}=$ Kabenhavns Stadsarkiv

LAK = Landsarkivet $\mathrm{i}$ Kobenhavn

RA = Rigsarkivet $i$ København

ST $\AA=$ Statsbiblioteket $\mathbf{i}$ Århus

AAR: Protokol over årsprøverne i Sorø Akademis Larde Skole 1890-1902. LAK.

AN: Aksel Nellemann og Knud Moseholm: Lærere ved Kolding Latin- og Realskole og Kolding Højere Almenskole 1880-1930. Kolding 1991.

ANS: Ansøgninger om gejstlige embeder 1853-1915. Kultusministeriet 1 . kontor. Kontor for kirkevæsen. RA 06/1-2891.

BE: Beneficiesager vedr. Sorø Akademis Skole 1895-1901. Ministeriet for Kirkeog Undervisningsvæsen. 3. kontor. RA 06/3-3072 + 3073 .

BR: To breve fra Ernst Kiørboe til professor Johs. Steenstrup, Kobenhavns Universitet. Brevene er dateret henholdsvis 29/1-1908 i Kolding Præstegård og 2/51908 i Paris. KB. Håndskriftssamlingen. Nks 5016.

CA: Cæciliaforeningens Arkiv. KB.

CE: Claus Eskildsen m.fl.: Tønder Amt. Særtryk af "Sonderjylland". Ribe amts historiske forlag. 1936.

EP: Eksamensprotokol for studentereksamen ved Sorø Akademi år 1900. LAK.

FA: Undervisningsministeriet. Gruppeordnede sager. Sager vedr. fag- og timefordeling ved Tønder Statsskole 192039. RA.

FI: Den filosofiske eksamen. Hovedkarakterprotokol 1899-1911. RA 35.18.05.
FK: De forenede Kursus. Budget, regnskab, lærerlister m.v. 1908-1921. LAK.

FO: Forholdsbog for disciplene ved Soro Akademi 1896-1920. Rektors opnotering af disciplinærsager. LAK.

FT: Folketællinger. RA.

GR: Undervisningsministeriet. Gruppeordnede sager. Ansegningsprotokol for embeder under undervisningsministeriet 1913-57. RA.

GU: Guldhornet. Tønder Statsskoles elevblad.

HE: Paul Hedemann: Pastor William Kiørboe. Schæffers Forlag. Kolding 1926. KB 44-172.

JL: Johan Larsen: Mennesker i Tonder. Th. Laursens Bogtrykkeri. Tønder. 1967.

JO: Journalsager. Undervisningsminsteriet. RA.

JU I: Tønder Statsskoles Jubilæumsbog 1935.

JU II: Tønder Statsskoles Jubilæumsbog 1945.

JU III: Tønder Statsskoles Jubilæumsbog 1970.

JU IV: Tønder Statsskoles Jubilæumsbog 1995.

K I: V. Kiørboe og W. Kiørboe: Optegnelser vedrorende Familien Kiørboe. H. H. Thieles Bogtrykkeri. København 1910. RA CII Litra K.

K II: Frederik og Henning Kiørboe: Optegnelser vedrørende Familien Kiørboe. W. J. Christensens Bogtrykkeri. København 1937. STÅ.

K III: Lars Kiørboe, Preben Kiørboe og Jargen Kiørboe (red.): Optegnelser vedrerende Familien Kiørboe. København 1981. RA CII Litra K.

KO: Kopibøger. Undervisningsministeriet. RA.

LØ: Undervisningsministeriet. Gruppeordnede sager 1916-68. Lonninger ved statsskolerne og Sore Akademi 1915-24. RA.

MA: Protokoller over studenterne, "Matrikler«, 1829-1901. Københavns Universitet. RA 12.16.04.

ODS: Otto Didrik Schack: Grænsesind. Optegnelser fra årene 1913-49. Udgivet af Hans Schack i 1970 i anledning af 50 året for Genforeningen. Gyldendal.

OS: Opgave- og sporgsmålsbog 18921914. Kobenhavns Universitet. RA 35.10 .04 
PA: Sognepræst Carl William Kiørboe (†1930) og hustrus arkiv. RA 5767.

PE: Pastor emeritus Carl William Kiørboes begravelse på Refsnæs Kirkegård den 11. december 1930. Udgivet af hans børn. KB 44-172.

PO: Politiets registerblade 1890-1923. KS.

PR: Protokol over ansegere til præstekald 1897-1913. RA 06/1-2715.

RE: Regensianerne 1895-1919. Samlede i anledning af Regensens 300 års jubilæum. Biografier. Arnold Busck. København 1923.

RS: Refnæs sogns kirkebog 1866-88.

SAA: Sønderjyske Årbøger.

SA: Sammentællingsprotokoller for Sorø Akademis Skole 1886-1905. LAK.

SE: Skoleembedseksaminer ved Det filosofiske Fakultet ved Kobenhavns Universitet 1906-1909. RA 35.10.07.
SK: Skoleplaner for Kolding højere Almenskole 1918-20. Undervisningsministeriet. 2. departement. RA.

SM: Sønderjysk Månedsskrift.

SOB: S. Otto Brenner: Slægten Laub. Personalhistorisk Instituts Forlag. København 1929.

SSG: Sønderjyder siden Genforeningen. Erindringer. Redigeret af Lars N. Henningsen og Niels $H$. Kragh-Nielsen. Sonderjyske levnedsløb nr. 28. Historisk Samfund for Sønderjylland. Aabenraa 1995.

TSAA: Tønder Statsskoles Årsskrifter.

VE: Interview af Ernst Kiørboe i Vestkysten, Ribe-Tonder, $i$ anledning af dennes 80 års dag den 11. februar 1963. 